\title{
Diversity of enterovirus sequences detected in oysters by RT- heminested PCR
}

\author{
Eric Dubois ${ }^{\mathrm{a}^{*}}$, Ghislaine Merle ${ }^{\mathrm{a}}$, Catherine Roquier ${ }^{\mathrm{a}}$, Aurélien Trompette $^{\mathrm{b}}$, \\ Françoise Le Guyader $^{c}$, Catherine Crucière $^{a}$ and Jean-Jacques Chomel ${ }^{b}$
}

\author{
${ }^{a}$ Secteur de Virologie des Aliments et de l'Eau, Agence Française de Sécurité Sanitaire des Aliments, 22, rue \\ Pierre Curie, B.P. 67, 94703, Maisons-Alfort cedex, France \\ ${ }^{\mathrm{b}}$ Centre National de Référence des Entérovirus, Laboratoire de Virologie, Université Claude Bernard Lyon I, 8, \\ avenue Rockefeller, 69373, Lyon cedex 08, France \\ 'Laboratoire de Microbiologie, IFREMER, B.P. 21105, 44311, Nantes cedex 03, France x \\ *: Corresponding author : Tel.: +33-149-771-300; fax: +33-143-689-762. e.dubois@afssa.fr
}

\begin{abstract}
Oysters harvested in western France, from five sites associated with outbreaks of foodborne norovirus gastroenteritis between February 2000 and March 2001, were assayed for enterovirus RNA by reverse transcriptase-heminested polymerase chain reaction (RT-heminested PCR). Forty percent $(21 / 52)$ of shellfish samples (pool of seven oysters) were contaminated by enteroviruses. Infectious coxsackieviruses serotype A21 were isolated from three of these positive samples. Amplicons corresponding to 65 base sequences in the $5^{\prime}$ untranslated region of the enteroviral genome were analyzed by direct sequencing. Interpretable results were obtained from 18 amplicons, but mixtures of sequences confused the results from 3 samples. Sequences isolated from samples from the different sites were different but similarities were observed between sequences detected in shellfish from two sites at different dates. Sequences were also compared to sequences of human, bovine and porcine enteroviruses. Both human and animal origins of enterovirus contamination of shellfish seemed likely.
\end{abstract}

Keywords: Enterovirus; Shellfish; Cell culture; RT-PCR; Sequence analyze 


\section{Introduction}

Enteroviruses are non-enveloped enteric RNA viruses belonging to the family Picornaviridae. These viruses infect human and a wide range of mammals, including cattle and pigs (Ruecker, 1996). Infected humans or animals excrete feces containing viral particles, which remain infectious for several days in environmental water (Wait and Sobsey, 2001). Human enteroviruses have been detected in water, sewages, sludge and shellfish, and are used, notably in Europe, as indicator of fecal contamination of drinking or bathing waters (Anonymous, 1975, 1980). However, these viruses are not indicators of hazardous viral contamination, because recent studies found that contamination of shellfish with pathogens such as hepatitis A virus (HAV) or Norwalk-like viruses (NLV) was not correlated with the presence of enteroviruses (Le Guyader et al., 1994; Le Guyader et al., 2000, Romalde et al., 2002). Reduction in the frequency of enterovirus detection has probably arisen because attenuated poliovirus vaccine strains are now not excreted by the human population, and because of changes in the epidemiology of enterovirus infections. Nevertheless, non-poliovirus enteroviruses are still associated with acute diseases and, possibly, with chronic disease, and were responsible for large outbreaks of meningitis in France and Europe in 2000-2001 (Chambon et al., 2001). During these outbreaks, as in most enterovirus outbreaks, inter-human transmission seemed likely. However, the mode of transmission is difficult to discern and in a few cases waterborne outbreaks have been described (Melnick, 1996). Epidemiological surveillance plays an essential role in the control of infectious diseases. The detection of viruses in both clinical and environmental samples may help understanding of the mode of transmission of strains responsible for human infections. In France, as recommended by the World Health Organization (WHO) for eradication of wild poliovirus, enteroviruses detected from sewages and/or sludge have to be titrated and characterized (World Health Organization, 2000). However, there has been no systematic identification of enteroviruses found in shellfish.

During our investigation of Norwalk-like gastro-enteritis associated with oyster consumption (Dubois et al., 2001; Le Guyader et al, 2003), we searched for enteroviruses in the shellfish using a novel combination of previously published primers (Abbasadegan et al., 1993; Leparc et al., 1993) for the reverse transcriptase-heminested polymerase chain reaction (RT-heminested PCR). This method was chosen because of its high specificity and sensitivity for viral RNA detection (Dubois et al., 2002). Our objectives were to evaluate the frequency of detection of enteroviruses and to identify the strains origin. This note presents the results of the enterovirus RNA amplification, the amplicon sequencing, and the virus isolation by cell culture. 


\section{Materials and methods}

\subsection{Viruses and cells}

Poliovirus type 1 (Sabin strain) was used in this study as an enterovirus model for evaluating the sensitivity of the reverse transcriptase-polymerase chain reaction (RT-PCR). The virus was grown on Vero cells (Membres de la commission de normalisation, 1989). Poliovirus particles $(\mathrm{d}=1.34)$ were purified by isopycnic centrifugation in a $\mathrm{CsCl}$ density gradient. Virus titration was carried out on Vero cells in microtitration plates and expressed as 50\%-tissue culture infectious dose $\left(\mathrm{TCID}_{50}\right)$ per volume unit (Membres de la commission de normalisation, 1989). The titer of the poliovirus stock was $1.8 \times 10^{8} \mathrm{TCID}_{50} / \mathrm{ml}$. Assuming that the Poisson model was applicable to the viral samples analyzed, 1 $\mathrm{TCID}_{50} / \mathrm{ml}$ was equivalent to $0.69 \mathrm{PFU} / \mathrm{ml}$ (Maul et al., 1991). Consequently, the titer of poliovirus stock was equivalent at about $1.2 \times 10^{8} \mathrm{PFU} / \mathrm{ml}$. The titer of stock was also determined as RT-PCR amplification units (RT-PCRU) by endpoint dilution, heating to release the viral genome from capside, and then performing RNA detection by RT-heminested PCR. Given that the last positive dilution contained one RT-PCRU, the titer was estimate to be about $1.2 \times 10^{10}$ RT-PCRU/ml (mean of three different experiments). Consequently, 1 TCID $_{50}$ of poliovirus was equivalent to about 67 RT-PCRU.

\subsection{Shellfish samples}

Oysters (Crassostrea gigas) associated with gastro-enteritis outbreaks (Haeghebaert et al., 2002) were collected by veterinarian inspectors. Five different sites were targeted. Site A (South Brittany, Atlantic Ocean) was sampled between February and May 2000; site B (North Brittany, English Channel) between March and May 2000; site C (North Brittany, English Channel) between January 2001 and March 2001; site D (Normandy, English Channel) in December 2000; and site E (Normandy, English Channel) during January and February 2001. Shellfish were kept frozen or refrigerated during shipment. The samples reached the laboratory one day after collection. On arrival, all shellfish were stored at $-20^{\circ} \mathrm{C}$.

\subsection{Viral concentrations in oyster digestive glands}

Viral concentrations were determined by a procedure adapted from the protocol previously described by Atmar et al. (1995). Briefly, $3 \mathrm{~g}$ of digestive gland removed by dissection from 7 shellfish were homogenized in $15 \mathrm{ml}$ of phosphate-buffered saline solution $\mathrm{pH} 7.4$ (PBS). After addition of one volume of chloroform-butanol $(1: 1 \mathrm{v} / \mathrm{v})$, the mixture was shaken vigorously for $1 \mathrm{~min}$, then $150 \mu \mathrm{l}$ of Cat-Floc $20 \%$ in water (Sigma-Aldrich, Saint-Quentin-Fallavier, France) was added. After rocking for $5 \mathrm{~min}$ and settling for $15 \mathrm{~min}$ at room temperature, the suspension was centrifuged at $10,000 \times \mathrm{g}$ for $15 \mathrm{~min}$ at $4^{\circ} \mathrm{C}$. The aqueous solution was recovered and supplemented with polyethylene glycol 6,000 (Promega, Lyon, France) and $\mathrm{NaCl}$ (Sigma-Aldrich) to obtain final concentrations of $10 \%$ and $0.3 \mathrm{M}$, respectively. After homogenization and settling overnight at $4^{\circ} \mathrm{C}$, the mixture was centrifuged at $10,000 \mathrm{x} \mathrm{g}$ for $1 \mathrm{~h}$ at $4^{\circ} \mathrm{C}$. The pellet was then suspended in $2.5 \mathrm{ml}$ of water and stored at $-80^{\circ} \mathrm{C}$ until use. 


\subsection{Identification of infectious enterovirus}

One $\mathrm{ml}$ of each viral concentrate positive for enterovirus RNA was stored at $-20^{\circ} \mathrm{C}$ and forwarded to the National Reference Center for Enterovirus for enterovirus isolation. Sample was diluted in culture medium (1/100) and inoculated on five different confluent mono-layers cell lines (BGM, MRC5, Hep2, HRT, and L20B). Three consecutive, 8-days subcultures were used to allow detection of cythopatic effects. Identification of virus was carried out by neutralization test using the "LBM" WHO intersecting pools of hyperimmune antisera against enteroviruses (Schnurr, 1992).

\subsection{RNA extraction}

RNAs were purified using the RNA-Plus purification kit (QBiogène, Illkirch, France) according to the manufacturer's instructions. Briefly, $500 \mu \mathrm{l}$ of viral concentrate were mixed with two volumes of guanidinium thiocyanatephenol-chloroform solution. The aqueous phase was separated from the organic phase by centrifugation. The RNAs were recovered by isopropanol precipitation, washed with $75 \%$ ethanol, and dissolved in $50 \mu \mathrm{l}$ of sterile water.

\subsection{Oligonucleotides}

The primers used for the amplification of poliovirus RNA were selected in the 5' noncoding region of the enteroviruses (Abbaszadegan et al., 1993; Leparc et al., 1993). The antisense primer (5' ATTGTCACCATAAGCAGCCA 3', base 596 to 577) was designated primer 3 , the sense primer (5' TCCGGCCCCTGAATGCGGCT 3', base 446 to 465) was designated primer A1, and the internal antisense primer was designated primer A2 (5' CCCAAAGTAGTCGGTTCCGC 3', base 550 to 531). All the map positions refer to poliovirus type 1 Sabin strain (accession number: V01150).

\subsection{Amplification of RNAs}

An RT-heminested PCR method for detection of enteroviruses contaminating vegetal surfaces was previously described (Dubois et al., 2002). This method was adapted for shellfish analysis, by doubling the reaction volume of RT-PCR to increase the proportion of analyzed sample. RNA extract ( $6 \mu \mathrm{l})$ was analyzed by RT-PCR in a single tube. The $20-\mu \mathrm{RT}$ mixture was made of $1 \mathrm{X}$ PCR Gold Buffer (Applied Biosystems, Courtaboeuf, France), $2.5 \mathrm{mM} \mathrm{MgCl}_{2}$, $500 \mu \mathrm{M}$ of four deoxynucleoside triphosphates, $1.25 \mu \mathrm{M}$ of downstream primer (primer 3), $5 \mathrm{U}$ of RNase Inhibitor (Applied Biosystems), and $12.5 \mathrm{U}$ (Applied Biosystems) of MuLV reverse transcriptase (Applied Biosystems). The mixture was incubated for $1 \mathrm{~h}$ at $42^{\circ} \mathrm{C}$, and the enzymes were then inactivated at $95^{\circ} \mathrm{C}$ for $5 \mathrm{~min}$. PCR was carried out in a $100 \mu \mathrm{l}$ reaction mixture containing $1 \mathrm{X}$ PCR Gold Buffer, $1.5 \mathrm{mM} \mathrm{MgCl}_{2}, 200 \mu \mathrm{M}$ deoxynucleoside triphosphates, $0.25 \mu \mathrm{M}$ of downstream and upstream primers (primer 3 and primer A1), and $1.5 \mathrm{U}$ of AmpliTaq Gold (Applied Biosystems). Heminested PCR was performed with $2 \mu \mathrm{l}$ of the amplified product used as a template, in a $25-\mu$ l reaction mixture of the same composition as that used for PCR, except that the primer set was composed of the internal and the upstream primers (primer A2 and primer A1). A negative 
amplification control (water) was included in each amplification series. The cycling conditions were as follows: initial preincubation at $93^{\circ} \mathrm{C}$ for 9 min $(12$ min for heminested PCR); 40 cycles (30 cycles for heminested PCR) with denaturation at $94^{\circ} \mathrm{C}$ for $30 \mathrm{~s}$ and annealing/extending at $60^{\circ} \mathrm{C}$ for $1 \mathrm{~min}$; and a final extension at $60^{\circ} \mathrm{C}$ for $10 \mathrm{~min}$. Amplified products, $151 \mathrm{bp}$ and $105 \mathrm{bp}$ in length after RT-PCR and heminested PCR, respectively, were detected by polyacrylamide gel electrophoresis and ethidium bromide staining. To avoid falsepositive results associated with heminested-PCR, separate rooms were used for RT-PCR and heminested-PCR master-mix preparation, sample processing, DNA amplification, and amplicon detection.

\subsection{Sequence analysis}

Both strands of amplicons were sequenced by GenomeExpress (Grenoble, France), directly from heminested-PCR reactions with Taq DyeDeoxy Terminator cycle-sequencing kit and ABI 373XL automate sequencer (Applied Biosystems). Sequences of 65 bases (corresponding to nucleotides 466 to 530 of poliovirus genome) were analyzed with Lasergene software (DNAStar, Madison, Wisconsin).

\section{Results and discussion}

\subsection{Sensitivity of shellfish analysis evaluated by RT-heminested PCR}

Four experiments were performed with oysters negative for enterovirus RNA detection. Digestive glands ( $3 \mathrm{~g}$ ) were inoculated with $4.6 \times 10^{1}$ to $4.6 \times 10^{-3}$ TCID $_{50}$ of poliovirus and processed for viral detection. In three experiments, viral RNA was detected in digestive glands inoculated with $4.6 \times 10^{-1} \mathrm{TCID}_{50} / 3 \mathrm{~g}$ (about $3.2 \times 10^{-1} \mathrm{PFU} / 3 \mathrm{~g}$ or $3.1 \times 10^{1} \mathrm{RT}$-PCRU/3g) (Fig. 1). In the other experiment viral RNA was detected at a 10 -fold higher concentration. Given the proportion of samples analyzed (2.4\%), these results suggested that RTheminested PCR reaction was likely to detect $1.1 \times 10^{-1}$ to $1.1 \times 10^{-2}$ TCID $_{50}$ (about $7.6 \times 10^{-2}$ to $7.6 \times 10^{-3}$ PFU or $7.4 \times 10^{0}$ to $7.4 \times 10^{-1}$ RT-PCRU) as enumerated by cell culture assay. According to these results, the efficiency of the virus concentration and RNA purification process was estimated to be about $105 \%$ (mean of three experiments in which efficiencies ranged from 13.5 to 135\%). The detection method was at least as sensitive as previously reported methods that used poliovirus for their evaluation. For example, De Medici et al. (1998) detected 1 TCID $_{50}$ per 10 g of mussels, Häfliger et al. (1997) detected 3 to 30 TCID $_{50}$ per $1.25 \mathrm{~g}$ of mussel or oyster, and Dix and Jaykus (1998) detected $10^{3}$ PFU per $50 \mathrm{~g}$ of hard-shelled clams. Our results were also comparable to those of a method recently evaluated with HAV and NLV, with which sensitivities were about 0.015 PFU and 22.4 RT-PCRU per $3.75 \mathrm{~g}$ of shellfish, respectively (Kingsley and Richards, 2001). As compared with the original method (Atmar et al., 1995), the increased sensitivity seemed to be associated with improvements of RNA purification and viral RNA detection by RT-heminested PCR. 
Fig. 1. Detection sensitivity of poliovirus inoculated in oyster digestive glands, by RT-heminested PCR. Digestive glands were inoculated with poliovirus (Sabin strain) and processed for viral RNA detection by RT-heminested PCR. Lanes 1 to -3 : $4.6 \times 10^{1}$ to $4.6 \times 10^{-3}$ poliovirus TCID $_{50}$ seeded in $3 \mathrm{~g}$ of tissus, respectively. Lanes S: non-seeded shellfish digestive glands. Lanes W: negative control for RT-heminested PCR (water). Lanes M: DNA molecular weight marker VIII (Boehringer Mannheim, Meylan, France).

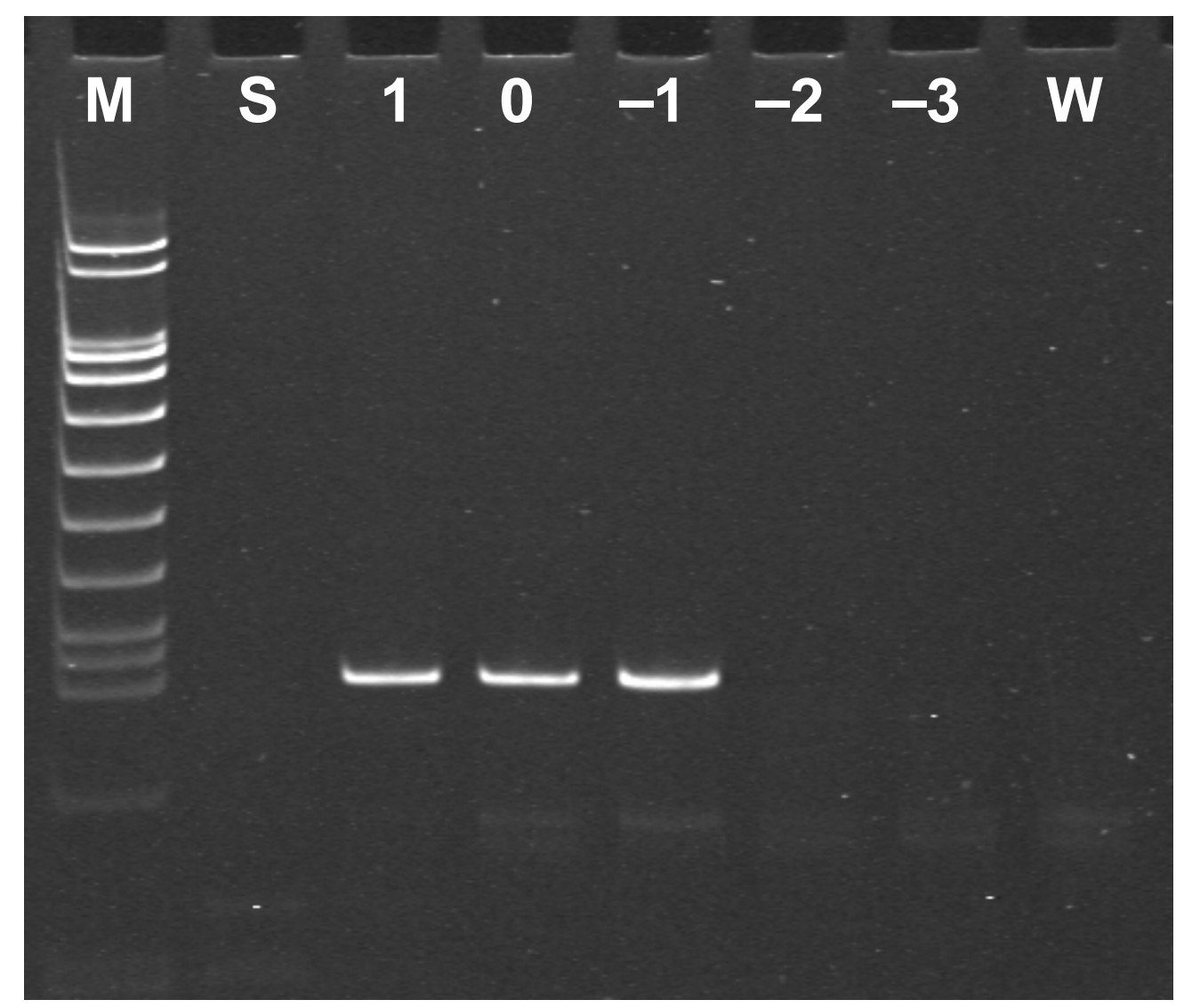

\subsection{Analysis of oyster samples}

Of the 52 shellfish samples that were processed, 21 (40.4\%) were positive for enterovirus RNA (Table 1). Infectious viruses were isolated from three samples, which were collected in April 2000 from site B, and were positive by RT-heminested PCR. For each sample, cythopatic effects were observed after three 8-days subcultures on MRC5 cells, and coxsackieviruses type A21 were identified by neutralization assay. The laboratory was also involved in the investigation of the association between oyster consumption and the gastroenteritis outbreaks. When we compared the results obtained from the same samples, no correlation was found between the presence of the aetiological agent of diarrhea and the presence of enteroviruses. About 24 oyster samples previously found contaminated by noroviruses, 8 (33\%) were not contaminated by enteroviruses (data not shown). 
Table 1

Detection of enterovirus RNA in harvested shellfish

\begin{tabular}{|c|c|c|c|c|c|}
\hline \multirow{2}{*}{ Date } & \multicolumn{5}{|c|}{ No. of positive samples/total no. of samples ${ }^{\mathrm{a}}$} \\
\hline & Site A & Site B & Site C & Site D & Site E \\
\hline \multicolumn{6}{|l|}{2000} \\
\hline Feb. & $1 / 1$ & & & & \\
\hline Mar. & $1 / 2$ & $0 / 3$ & & & \\
\hline Apr. & $0 / 7$ & $6 / 8$ & & & \\
\hline May. & $1 / 1$ & $2 / 4$ & & & \\
\hline Dec. & & & & & $1 / 6$ \\
\hline \multicolumn{6}{|l|}{2001} \\
\hline Jan. & & & $0 / 3$ & $0 / 1$ & \\
\hline Feb. & & & $4 / 8$ & $5 / 6$ & \\
\hline Mar. & & & $0 / 2$ & & \\
\hline
\end{tabular}

${ }^{a}$ Positive samples (pool of 7 oysters) refer to a positive result by RT-heminested PCR.

\subsection{Analysis of the sequences detected in oyster samples}

For the 21 positive samples, chromatogram results indicated that mixtures of at least 2 different viral sequences was present in 3 amplicons, while 18 samples gave interpretable sequencing results. These sequences were compared together and with the sequences of poliovirus strains grown in the laboratory (Fig. 2). No sequences were similar to those of poliovirus. Similarities were observed between sequences detected in shellfish harvested from the same sampling site on the same day and also on different days (Site A: EV-A000228, EV-A000309 and EV-A000515/b; Site D: EV-D010228/1 or 2, and EV-D010205/1). Cross contaminations between shellfish samples during experiments could be excluded because the RT-heminested PCR control and others oyster samples were negative. That is, no inhibition was detected in these samples by adding exogenous viral RNA and performing RT-heminested PCR. Moreover, no similarity was observed between the sequences of viruses isolated from shellfish from different sites. Distinct viral sequences were obtained from different shellfish batches harvested the same day from the same site (Site B : EV-B000517/1 and 2; Site C: EVC010220/1 and 2; Site D: EV-D010205/1 and 2). One sample analyzed in duplicate gave different enterovirus RNA sequences (EV-A000515/a and b). The three coxsackieviruses A21 isolated by cell culture were also sequenced (OMS 511/2000: Accession no. AY205253; OMS 512/2000: Accession no. AY205254; OMS 513/2000: Accession no. AY205255) and provided the same sequence of 65 bases (Fig. 2). However, the sequence was different from those obtained from the same sample by direct sequencing of the amplicons (nine bases different for EVB000403 and 18 for EV-B000405). 
Fig. 2. Alignment of the nucleotide sequences obtained from the 5 ' non-coding region of the enteroviruses detected in shellfish. The sequences are designated by the letter of the sampling site and a number matching to the year, the month and the day of sample collection. The number or latter after the slash indicates different sample harvested the same day or duplicate of one sample, respectively. The sequences of the viruses isolated by cell culture began by OMS according references providing by the National Reference Center for Enteroviruses.

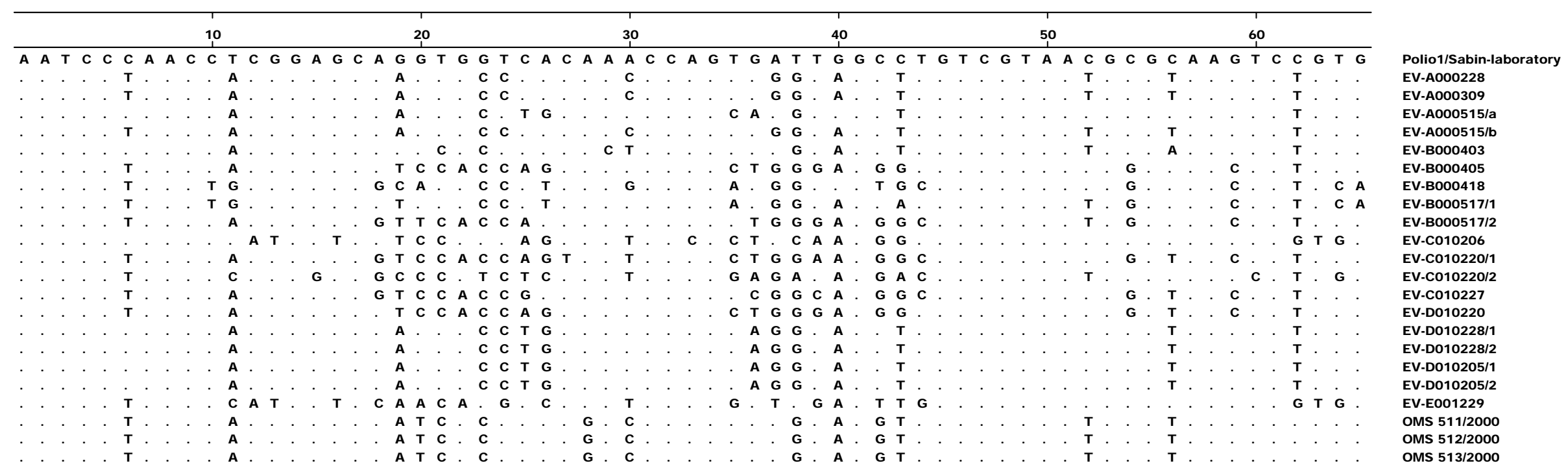




\subsection{Comparisons against the sequences in databases}

Similarities were observed between shellfish enteroviral RNA sequences and RNA sequences of reference strains of human and animal enteroviruses described in databases (Fig. 3). The phylogenetic tree, based on the similarities of sequences of 65 bases, showed different clusters. Within these clusters were grouped strains belonging to the same cluster according to a classification based on nucleotide identity of larger sequences also in the 5' untranslated region (Muir et al., 1998). Therefore, the analysis of short sequences might allow rapidly identification of strains. Among the three samples containing infectious coxsackieviruses serotype A21, two allowed the identification of viral sequences. One was closely related to a coxsackieviruses A21 (EV-B000403) the other to a porcine enterovirus (EV-B000405). The differences observed between the sequence EV-B000403 and the sequences of isolated coxsackieviruses A21 (OMS $512 / 2000$ ) from the same oyster sample might be a result of mutations during viral replication in cell culture. Nevertheless, higher discordances observed between molecular (EV-B000405) and neutralization assays (OMS 513/2000) from the same sample might be associated with the occurrence of two distinct viruses in the samples, as was shown for other samples; with one strain being more efficiency detected by RT-heminested PCR than the other, which was detected by cell culture only. The sequence analysis indicated also that 5 sequences among 19 characterized were probably close to porcine enteroviruses sequences and 3 were phylogeneticaly distant from the others strains (Fig. 3). The sequences were too short for assessing their relationship with the sequences of animal viruses, but the occurrence of porcine enterovirus in the environment could be possible as swine production is extensive in western France. Moreover, a high frequency of bovine enterovirus in stool from cattle, with the virus being in oysters collected from a river downstream from the farm has recently been reported (Ley et al., 2002). Others animal enteric viruses have also been detected in environmental samples. In particular, we previously characterized by restriction fragment length polymorphism assay rotavirus sequences in wastewater, and observed similarities with animal rotavirus profiles (Dubois et al., 1997). At the present time, there is no evidence that primers selected to evaluate the viral quality of shellfish and of water do not detect animal viruses, and the impact on human health of these animal viruses is still unclear. 
Fig. 3. Phylogenetic analysis of enterovirus sequences obtained from shellfish samples. The phylogenetic analysis was performed on 65-base nucleotide sequences from the 5' non-coding region of enterovirus genome (sequence between primer 3 and primer A1), with Lasergene software (DNAStar) by using clustal method. For reference strains, the last number indicates the identification number in GenBank. The scale represents the number of nucleotide substitution between the sequences. The arrows locate the viral sequences identified in this study. For human enteroviruses, cluster I and II was described by Muir et al (1998).

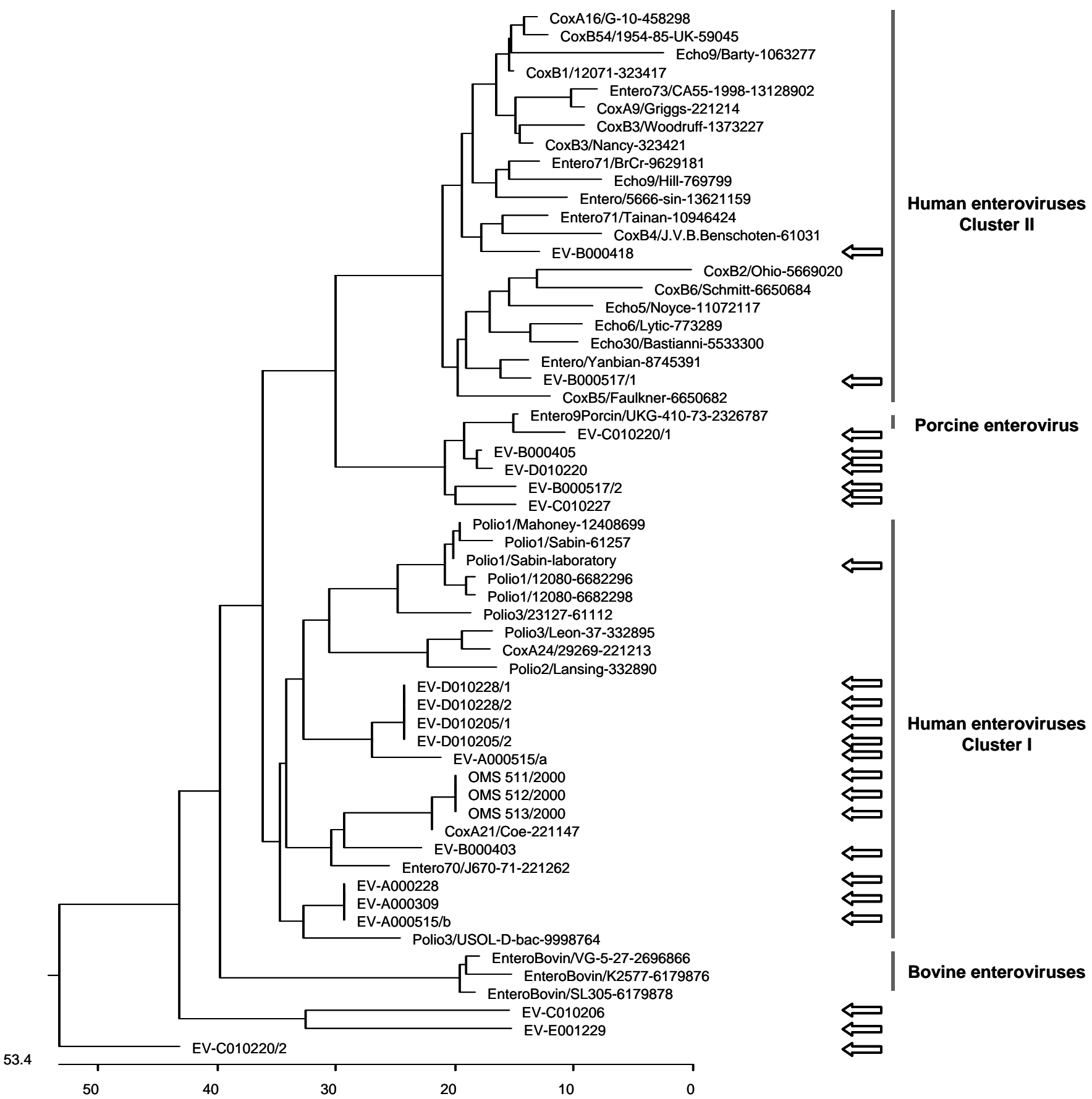




\subsection{Epidemiological background}

Most of the strains identified from shellfish were probably enterovirus strains that circulate in the human population, as has been previously demonstrated for rotavirus strains in sewage (Dubois et al., 1997). The frequency of detection of the enteroviruses found in this study was higher than that found for sites occasionally contaminated by fecal coliforms (Le Guyader et al., 2000). The percentage of positive samples was similar to that for enterovirus RNAs detected in shellfish collected from moderately polluted areas on the northwestern coast of Spain (Romalde et al., 2002). The shellfish analyzed in the present study came from probably polluted sites; so the results likely do not reflect the usual prevalence of viruses in French shellfish. The contamination of sites probably arose because of unusually heavy rains and runoff (Miossec et al., 1998), and of outbreaks of enterovirus infections (Lina et al., 2001).

\section{Conclusion}

The present study describes an important frequency (40\%) of enterovirus sequences detection, by RT-heminested PCR, in oysters exposed to fecal contamination. This result was probably associated with exceptional climatic (heavy winter rains) and epidemiological (large enteroviral outbreaks) factors. The characterization of viral sequences suggested that animal strains were also associated with the contamination of shellfish samples. These results highlight the usefulness of studies focused simultaneously on clinical, veterinarian and environmental samples for clarifying enterovirus ecology.

\section{Acknowledgements}

This work was supported by grant (S97/21) from the Direction générale de l'alimentation and from the Agence française de sécurité sanitaire des aliments.

We are grateful to Pierre Aubert and veterinarian inspectors (Direction générale de l'alimentation - Ministère de l'agriculture, de l'alimentation, de la pêche et des affaires ruralres) for shellfish sampling. We thank Labib BakkaliKassimi (Agence française de sécurité sanitaire des aliments, France) for helpful advices during phylogenetic analyse. 


\section{References}

Anonymous, 1975. Council directive of 8 December 1975 concerning the quality of bathing water (76/160/EEC). Official Journal of European Community, 05 February 1976, $\mathrm{N}^{\circ} \mathrm{L}$ 31, pp. 1.

Anonymous, 1980. Council directive of 15 July 1980 relating to the quality of water intended for human consumption (80/778/EEC). Official Journal of European Community, 30 August 1980, $\mathrm{N}^{\circ}$ L 229, pp. 11.

Abbaszadegan, M., Huber, M.S., Gerba, C., Pepper, I., 1993. Detection of enteroviruses in groundwater with the polymerase chain reaction. Applied Environmental Microbiology 59 (5), 1318-1324.

Atmar, R.L., Neill, F.H., Romalde, J.L., Le Guyader, F., Woodley, C.M., Metcalf, T.G., Estes, M.K., 1995. Detection of Norwalk virus and hepatitis A virus in shellfish tissues with the PCR. Applied Environmental Microbiology 61 (8), 3014-3018.

Chambon, M., Archimbaud, C., Bailly, J.L., Henquell, C., Regagnon, C., Charbonné, F., Peigue-Lafeuille, H., 2001. Circulation of enteroviruses and persistence of meningitis cases in the winter of 1999-2000. Journal of. Medical Virology 65 (2), 340-347.

De Medici, D., Beneduce, F., Fiore, A., Scalfaro, C., Croci, L., 1998. Application of reverse transcriptase-nested-PCR or detection of poliovirus in mussels. International Journal of Food Microbiology 40 (1-2), 51-56.

Dix, A.B., Jaykus, L.A, 1998. Virion concentration method for the detection of human enteric viruses in extracts of hard-shelled clams. Journal of Food Protection 61 (4), 458-465.

Dubois, E., Le Guyader, F., Haugarreau, L., Kopecka, H., Cormier, M., Pommepuy, M., 1997. Molecular epidemiological survey of rotaviruses in sewage by reverse transcriptase seminested PCR and restriction fragment length polymorphism assay. Applied Environmental Microbiology 63 (5), 1794-1800.

Dubois, E., Loisy, F., Le Guyader, F., Bon, F., Kohli, E., Chomel, J. J., Miossec, L, 2001. Contamination virale d'huîtres impliquées dans une toxi-infection alimentaire collective abstr. In Abstracts of the III ${ }^{\text {èmes }}$ jounrées francophones de virology, Société Française de Microbiologie, Paris, France, A94, pp. 38.

Dubois, E., Agier, C., Traoré, O., Hennechart, C., Merle, G., Crucière, C., Laveran, H., 2002. Modified concentration method for the detection of enteric viruses on fruits and vegetables by reverse transcriptase-polymerase chain reaction or cell culture. Journal of Food Protection 65 (12), 1962-1969.

Haeghebaert, S., Le Querrec, F., Gallay, A., Bouvet, P., Gomez, M., Vaillant, V., 2002. Les toxi-infections alimentaires collectives en France, en 1999 et 2000. Bulletin Epidémiologique Hebdomadaire 23/2002,105-109.

Häfliger, D., Gilgen, M., Lüthy, J., Hübner, Ph., 1997. Seminested RT-PCR systems for small round structured viruses and detection of enteric viruses in seafood. International Journal of Food Microbiology 37 (1), 27-36.

Kingsley, D.H., Richards, G.P., 2001. Rapid and efficient extraction method for reverse transcription-PCR detection of hepatitis A and Norwalk-like viruses in shellfish. Applied Environmental Microbiology 67 (9), 4152-4157.

Le Guyader, F., Dubois, E., Menard, D., Pommepuy, M., 1994. Detection of hepatitis A virus, rotavirus and enterovirus in naturally contaminated shellfish and sediment by reverse transcription-seminested PCR. Applied Environmental Microbiology 60 (10), 36653671.

Le Guyader, F., Haugarreau, L., Miossec, L., Dubois, E., Pommepuy, M., 2000. Three-year study to assess human enteric viruses in shellfish. Applied Environmental Microbiology 66 (8), 3241-3248. 
Le Guyader, F.S., Neill, F.H., Dubois, E., Bon, F., Loisy, F., Kholi, E., Pommepuy, M., Atmar, R.L., 2003. A semiquantitative approach to estimate Norwalk-like virus contamination of oysters implicated in an outbreak. International Journal of Food Microbiology xx (xx), xxx-xxx.

Leparc, I., Fuchs, F., Kopecka, H., Aymard, M., 1993. Use of the polymerase chain reaction with a murine model of picornavirus-induced myocarditis. Journal of Clinical Microbiology 31 (11), 2890-2894.

Ley, V., Higgins, J., Fayer, R., 2002. Bovine enteroviruses as indicator of fecal contamination. Applied Environmental Microbiology 68 (7), 3455-3461.

Lina, B., Chomel, J.J., Thouvenot, D., 2001. Annual report addressed to the World Health Organization -Copenhagen-Denmark

Maul, A., 1991. Aspects statistiques des méthodes de quantification en virologie. In Virologie des milieux hydriques, Tec \& Doc - Lavoisier, Paris, France, p. 143-171.

Melnick, J.L., 1996. Enteroviruses: poliovirus, coxsackieviruses, echoviruses, and newer enteroviruses. In B.N. Fields, D.N. Knipe, P.M. Howley, et al. (ed.), Fields Virology, third ed., Lippincott-Raven publishers, Philadelphia, chap. 22, pp. 655-712.

Membres de la commission de normalisation. 1989. Antiseptics and disinfectants used in liquid form and miscible with water-determination of virucide activity-viruses of vertebrates. French norm NF $\mathrm{T}$ 72-180. Association Française de Normalisation, AFNOR (ed.), Paris, France.

Miossec, L., Le Guyader, F., Haugarreau, L., Comps, M.A., Pommepuy, M., 1998. Possible relation between a winter epidemic of acute gastroenteritis in France and viral contamination of shellfish. Journal of Shellfish Research. 17 (5), 1661-1664.

Muir, P., Kämmerer, U., Korn, K., Mulders, M.N., Pöyry, T., Weissbrich, B., Kandolf, R., Cleator, G.M., van Loon, A.M., 1998. Molecular typing of enteroviruses: current status and future requirements. Clinical. Microbiololgy. Reviews. 11 (1), 207-227.

Romalde, J.L., Area, E., Sánchez, G., Ribao, C., Torrado, I., Abad, X., Pintó, R.M., Barja, J.L., Bosch, A., 2002. Prevalence of enterovirus and hepatitis A virus in bivalve mollusks from Galicia (NW Spain): inadequacy of the EU standards of microbiological quality. International Journal of Food Microbiology 74 (1-2), 119-130.

Ruecker, R.R., 1996. Picornaviridae: The viruses and their replication. In B.N. Fields, D.N. Knipe, P.M. Howley, et al. (ed.), Fields Virology, third ed., Lippincott-Raven publishers, Philadelphia, chap. 2, pp. 609-654.

Schnurr, D., 1992. Enterovirus. In E.H. Lennette (ed.), Laboratory diagnosis of viral infections, second edition, Dekker, chap. 16, pp. 351-364.

Wait, D.A., Sobsey M.D., 2001. Comparative survival of enteric viruses and bacteria in Atlantic ocean seawater. Water Science and Technology 43 (12), 139-142.

World Health Organization. 2000. Ninth meeting of the European region certification commission for the certification of poliomyelitis eradication. EUR/01/5018750, Denmark. 